Just what is the difficulty with this style of writing? Wherein lies the fallacy? Is it that what happens, in fiction or film, isn't what really matters? That in summarizing simply the plot, we omit the heart of the work (if, indeed, it had any)? Jack Hawkins' superb film, "Outcast in Malaya," is reduced to "the domestic problems of a rubber planter and his wife are solved by approaching jungle terrorists," and Dickens' "Pickwick Papers" to an "eye-opening tour of Britain."

That surely is at the nub of the problem. Great fiction and great film reflects life. And life, in an odd sort of way, isn't "about" anything. It isn't what happens that matters, but how it happens.

The writers of the guides show an almost studied shallowness of mind. Of one film they say: "Interesting sea story, confused by irrelevant detail and excess character development." Ah, if only these writers suffered from that same defect.

-ALBERT WILLIAM SADLER

\title{
PASSION AND WORSHIP
}

What is it that has made Peter Shaffer's Equus the substantive theatrical success it has been? If it achieves the distinction of becoming the play of the decade-and there seems little doubt that it will-it seems fair to say that it will have created something more than theatre history. (Sidney Lumet's realistic film adaptation will surely never have the same impact.) Equus is truly a cultural event of the richest sort. Like its decade, it is an index of quiet revolution.

The root of the play's popularity is, Ibelieve, to be found in exploring the two principal objections leveled against it. Although the critics have been fairly consistent in their praise of the play, Equus has been faulted for what is called a deliberately distorted view of psychiatry, and for concealing shallowness of thought behind the mask of brilliant theatre in its plea for passion over "The Normal."

Although theatre thrives on universal appeal, it presents individuals. The psychiatrist Martin Dysart, faced with Alan Strang's seemingly inexplicable blinding of six horses, is a particular man with his own problems. If he represents a weakness of psychiatry, he does it through the convincing revelation of his complex psyche. He stands neither for the emptiness of all healing nor for the glorification of one approach to contemporary psychiatry (R. D. Laing's equation of sanity with abnormality). Yet if the play had done nothing more than raise serious questions about the gods psychiatrists revere, about the image of wholeness that is the goal of their healing, it would have served our times well. It serves us, I propose, in a far more significant way.

The second objection is not as easy to answer; yet its resolution is linked to the first, and much more closely to the heart of the play's 
genuine enchantment. Does its "rhythm of incantation obscure absence of thought," as William Lynch observes (America, December 13, 1975)? Does it actually exploit "all its materials to create the single pinpointed ecstatic belief that passion, madness, and intuition are by far a better fate than the ordinary, the reasonable, the sane"'? Or, to put it in the briefer query of a close friend and collaborator, somewhat annoyed at the play after a third exposure to it, "Why must it be passion or normality? Why not passion and normality?"

Dysart's final monologue, Lynch barbs, "crowds every fraudulent cliché of the play into a curtain speech that no longer has any responsibility for articulating a single word of actual meaning." It is this speech, he claims, that whips the audience into a frenzy of deluded appreciation for shadow over substance. "The truth," Lynch repeats an octave higher, "would never measure up to the mad rhythm" of the "wild, rhetorical flood of sound." These objections, I feel, place too much emphasis on the letter of Dysart's harangue against society and not enough on its intimations. There is ultimately no question of choice. The play brings audiences to their feet precisely because of the strength of its plea for passion and normality, or more pointedly for passion and worship. It forces us to take a frighteningly close look at what we consider normal.

In building his argument against the play, Lynch misses the forest for the trees. Focusing on Dysart's "rhetorical attacks" against "The Normal," he notes that the psychiatrist denounces "reason, analysis, ordinariness, the middle class, his own psychiatric trade, his own wife and every companion item that is not instantly ecstatic," yet omits the most important items on the doctor's list. Dysart denounces himself! and the technological society that has immunized him to feeling! The theatrical truth is that the whole final monologue, which till now has been interpreted by at least four of the modern stage's finest actors, proceeds in the rhetorical mode of drama to deliver one of the most satisfying religious truths that a contemporary artist has dared to enunciate: that there is something dreadfully antiseptic about "life" today, that living is hardly worth the name. Thomas Marshfield, John Updike's distracted minister in A Month of Sundays, leaves us with a similar impression of sterilized religion. Noticing that the waitresses in the desert rehabilitation center approach him as if he were contaminated (and he insists that he suffers from "nothing less virulent than the human condition"), he notes in his diary: "A potential topic: touch and the sacred. God as Supreme Disease. Noli me tangere. Germs and the altar. The shared chalice versus the disposable paper cuplet."

The enemies of living-of worship and passion, to use Shaffer's language-are four: technology, psychiatry, religion, and even secular society (that one might otherwise assume to be so liberated and liberating). Positivism and/or rationalism, if not rationalization, permeate all. 
It is the fullness of this collusion that Shaffer shows has made even our sex passionless. "With any luck, his private parts," Dysart says of Alan, "will come to feel as plastic to him as the products of the factory to which he will almost certainly be sent." Then Dysart makes the almighty admission that one devoutly wishes to hear from all of the healing professions: "Passion, you see, can be destroyed by a doctor. It cannot be created." And even though the play does not name God as such, it so clearly speaks for the mystery that is at the heart of things-especially passion, enthusiasm, élan - that only the relentlessly traditional could deny its religious sensibility. Dysart hears Equus, Alan's god, demand of him: "Do you really imagine that you can account for Me? Totally, infallibly, inevitably account for Me? ... Poor Doctor Dysart!"

Lynch's principal objection, though, rests on his judgment that the play is "a miserable act of the imagination": unlike Euripides' Bacchae, he claims, it fails to reveal the dark side of Dionysus. Is there no tragedy in Alan's blinding of the six horses when the act clearly implies that he is killing his god? The tragedy of repressed passion is rooted here in the conflict between worship-a sense of place-and the hypocrisy of ordinary people. Those who feel ill at ease with the play's seeming indictment of Alan's mother's final simplistic appeal to the devil as the source of Alan's problem should take careful note that it is Frank, Alan's agnostic father, not Dora, whose hypocrisy releases Alan's demons. When Alan and Jill see him at the "skinflick" and he denies his prurient interest ("I had no idea they showed films like this," he lies), the insight that leads to tragedy bursts upon Alan like the eye of a hurricane. Men like his father make a secret god of pornography ("All the men-staring up like they were in church," Alan observes); even the irreligious conceal their sexual urges. "He's a man with a prick too. You know, I'd never thought about it," Alan confesses to Jill. He knows now that his sexual awakening is nothing singular. When Jill invites him to make love in the stable-unfortunately, because it is the temple of Equus-society's collective taboos drive him to the frenzied rage that is the tragedy the play seeks to analyze. Despite the fact that the door to the horses' stalls is closed, Alan feels the oppressive presence of his god's eyes. "Lie with anyone and I will see," they say. It is certainly not God, though, who reserves passion exclusively for himself; it is religion-man's response to God-and secular culture that attempt to make passion a dark secret thing of the night.

Supporting this collusion of the sacred and the profane is the plasticity itself of a technological age. Secular society and religion at least preserve vestiges of sacred place. The enemies of Alan (the Hosts of Hoover, Philco, Remington, etc.) and the foes of Equus (the Hosts of Jodhpur and Bowler that clothe his nakedness) are the overt deniers of flesh, the minions of plastic. When Dysart, whose annual "surrender to 
the primitive" shrines of ancient Greece is prepackaged and thoroughly sanitary ("every bed booked in advance, every meal paid for by vouchers, cautious jaunts in hired Fiats, spongebag crammed with EnteroVioform") cries out that "life is only comprehensible through a thousand local Gods," he is making a plea for a return to a sense of the sacred that a theologian especially ought not to miss. Modern living has not only extinguished our sense of the "living Geniuses of Place and Person," it has annihilated "even the idea of Place!" Delivering Alan back to "The Normal" is surrendering him-with regret-to "six-lane motorways driven through the guts of cities," to a land "cemented over from one sea to the next," and to waters "stinking dead under three inches of sun tan oil."

The play's most obvious statements about passion are negations: It cannot exclude sexual awareness. Sex must not be feared. That much is essential to human passion. Passion also involves sensitivity to touch and being at ease with nakedness. However incompletely, worship and passion are presented by Shaffer with justification as expressions of the fullness of human nature-fleshed spirit. Whatever the definition of passion, one would expect the hierarchical Church to feel nothing but uneasiness when the question of its relationship to worship is raised; our official moral theology, to give but one example, continues to imprison people behind walls of distinctions and subdistinctions. Nevertheless. in an age concerned about sexual awareness, some approved treatises on morality dare to remind priests and religious that they cannot deny the psychosexual basis of their personalities. To claim that sexuality is expressed in everything we do though, while denying the human need for genital expression, is an equivocation that even the voices of sexual sanity have had to resort to as an interim step in the evolution of moral sensibility within the Church. The continuing hubbub over Human Sexuality and similar works, including John MacNeil's The Church and the Homosexual, is clear indication that the hierarchy is still adamant in refusing to admit that the normal personality is psychosexual.

The perpetuation of the Church's discipline of celibacy is evidence enough of the endurance of the heresy of angelism that Peter Shaffer sees as a source of Alan Strang's illness. There is no better way to insinuate the divorce of passion and worship than to imply that those who preside over worship can live as if sexual passion were not an integral part of their lives, but would, like sweets during Lent, be offered up to appease an offended God. Another way to support that divorce is to reserve all touch in liturgy for the head, except for the recently "restored" gesture of peace and the typically avoided routine anointments in the Sacrament of the Sick. Champions of tradition will support this world against the implications of Equus because it is doubtlessly a safe one, this rational world of enforced celibacy that Roman Catholicism has held onto for 
dear life since the cataclysm of the sixteenth century and for who knows how many centuries before that without worry because, apparently, it was generally ignored.

To protect itself against passion the Church has been forced into the hypocrisy of its "vessel of clay" theology of celibacy. What is universal ought not to be considered a weakness (indeed a sin) to be confessed and forgiven. Since the Church's ministers and servants are expected to live as if they did not have bodies, there can be only guilt, confusion, and gross rationalization. (A friend who is a divinity student recently told me that all of the other members of his community-ten men within a year or two of ordination-were seeing psychiatrists.) A point that Colleen McCullough's bestselling novel The Thorn Birds makes so poignantly is that the humanity of our priests-especially of the hierarchy-must necessarily be "off the record." However humane a vessel-of-clay theology is for the erring cleric, it is nothing less, McCullough suggests, than a conspiracy of proud men wanting to be angels. We have lived regrettably long with the neurosis of Miriam's mother in D. H. Lawrence's Sons and Lovers. "Love is a matter of the spirit," she tells her daughter, "if you have it inside, there is no need to show it with arms and limbs."

It may be one of the quiet ironies of the Seventies that The Thorn Birds, like Equus, will have contributed more genuine insight into the sin of denied passion-and mandatory celibacy - than all of the theological tracts of the decade, in fact of any decade since the fury of the Reformers was unleashed on Rome four centuries ago. The excellence of art lies precisely in its capacity to reach the whole person, to make the heart feel the horror that the mind knows.

-JOHN R. MAY 